Research Report No. 35/2009

\title{
Turning the Curriculum Upside Down: Comparative Law as an Educational Tool for Constructing Pluralistic Legal Mind
}

Jaakko Husa

Follow this and additional works at: http:/ / digitalcommons.osgoode.yorku.ca/clpe

\section{Recommended Citation}

Husa, Jaakko, "Turning the Curriculum Upside Down: Comparative Law as an Educational Tool for Constructing Pluralistic Legal Mind" (2009). Comparative Research in Law \& Political Economy. Research Paper No. 35/2009.

http://digitalcommons.osgoode.yorku.ca/clpe/147 


\section{Comparative Research in Law \& Political Economy}

Jaakko Husa

Turning the Curriculum Upside Down: Comparative Law as an Educational Tool for Constructing Pluralistic Legal Mind

EDITORS: Peer Zumbansen (Osgoode Hall Law School, Toronto, Director, Comparative Research in Law and Political Economy, York University), John W. Cioffi (University of California at Riverside), Nassim Nasser (Osgoode Hall Law School, Toronto, Production Editor)

Also available at: http://www.germanlawjournal.com 



\section{German Law Journal}

Turning the Curriculum Upside Down: Comparative Law as an Educational Tool for Constructing Pluralistic Legal Mind

Jaakko Husa

10 German Law Journal 913 (2009), available at:

http://www.germanlawjournal.com/article.php?id=1129

This article was originally published in Volume 10, Number 7 of the German Law Journal as part of the journal's $10^{\text {th }}$ anniversary symposium on "Transnationalizing Legal Education" edited by Nadia Chiesa, Adam de Luca, and Bernadette Maheandiran. 
CLPE Research Paper 35/2009

Vol. 05 No. 06(2009)

\title{
Jaakko Husa \\ TURning The CuRriculum UPSIDE DOWN: CoMPARATIVE LaW AS AN Educational Tool for Constructing Pluralistic Legal Mind
}

\begin{abstract}
The argument in this paper draws inspiration from the pedagogical theory of so-called constructivism. An effective law curriculum is one which can stimulate students to learn legal thinking. The constructivist approach suggests that the learner is more actively involved in a joint enterprise with the law teacher of constructing new legally relevant, and perhaps competing, meanings. Comparative law and/or foreign law and even approximate knowledge of different foreign approaches to similar types of questions may be regarded as a valuable tool for the construction of a primary pluralistic legal mind.
\end{abstract}

Keywords: Legal education, Constructivist approach

JEL classification: K10, K40

Jaakko Husa

Professor of Constitutional Law and General Jurisprudence at the University of Joensuu and an Invited Fellow with the Tilburg Institute of Comparative and Transnational Law.

During the academic year 2008-2009 he is working at the University of Lapland as a Professor of Public Law.

Email: jaakko.husa@joensuu.fi 



\title{
SPECIAL ISSUE: TRANSNATIONALIZING LEgaL EdUCATION
}

\section{Turning the Curriculum Upside Down: Comparative Law as an Educational Tool for Constructing the Pluralistic Legal Mind}

\author{
By Jaakko Husa*
}

\author{
"Though this be madness, yet there is method in't." \\ Shakespeare's HAMLET (Act 2, Scene 2)
}

\section{A. Introduction}

As is well known, comparative law enters the curriculum normally only after some substantive law has been learned. The traditional approach first takes the law student's national legal system, with the comparison or foreign law element only coming later as a form of supplement to the standard curriculum. This paper offers some thoughts concerning the teaching and learning of law in a world in which pluralistic and/or transnational elements are commonplace. These plural features stem from the declining authority of the nation state as well as from the strengthening of various forms of subnational law being in tension with the central system of the state. These developments also include growth of supranational or transnational legal regimes (e.g. EU). ${ }^{1}$ The growth of the significance of human rights, especially the considerable growth of the system of the European Convention on Human Rights, has caused national and international legal spheres to overlap. This paper is based on a belief according to which future legal education ought to respond more seriously to the globalisation of law. ${ }^{2}$ However, the argument here is preliminary and it offers merely a sketch of essential features with scarce details i.e. this paper is of a somewhat rough design. The theme itself, i.e. transnational law and its effects, is most certainly somewhat fashionable these days. ${ }^{3}$

\footnotetext{
* Jaakko Husa is Professor of Constitutional Law and General Jurisprudence at the University of Joensuu and an Invited Fellow with the Tilburg Institute of Comparative and Transnational Law. During the academic year 20082009 he is working at the University of Lapland as a Professor of Public Law. The author is grateful for comments by Professor Petri Keskitalo. Email: jaakko.husa@joensuu.fi

${ }^{1}$ About the concept of transnational law, see Peer Zumbansen, Transnational Law, in ELGAR ENCYCLOPAEDIA Of LAW, 738 (Jan Smits ed. 2006).

${ }^{2}$ This is also the basic rationale behind the North American Consortium of Legal Education (NACLE). See Barbara Atwood, Graciela Jasa Silveira, Nicole LaViolette, and Tom Oldham, Crossing Borders in the Classroom: A Comparative Law Experiment in Family Law, 55 Journal of Legal EduCATION 542, 542-547 (2005).

${ }^{3}$ For example, when the Association of American Law Schools organised the Annual Meeting in January 2006 there was an all day workshop called Integrating Transnational Perspectives into First Year Curriculum.
} 
The problem with the traditional law-teaching approach is that it constructs a primary epistemic foundation for legal understanding, which is based on the one mother-system. This creates an implicit mono-epistemology, which makes lawyers regard their own system as 'normal' and other systems as 'not-normal' or, at least, something that is 'less-normal'. From this mono-epistemic platform, the law-student is first immersed in the oneapproach-thinking, which later makes it difficult to epistemologically adapt to transnational pluralism and to genuinely accept different approaches. Here it is tentatively argued that today's law-teaching should start from general legal questions without compulsory prior epistemic embedding to one's own national law. Shortly afterwards, students should first be introduced to different solutions and different ways to construct legal questions and ways for answering them. What is important to note in this context is that this is something more than just adding traditional international law or comparative law as a field of legal science in the law curriculum. ${ }^{4}$

The sketch-like argument in this paper draws inspiration from the pedagogical theory of so-called constructivism. In following this theory, one may say that in reality no one can teach law. Accordingly, an effective law curriculum is one which can stimulate students to learn legal thinking. So, law students learn law well when they construct their own legal understanding from multiple sources. If this idea is taken seriously, most teaching of national law should take place only after the first steps of the self-construction of the student's legal thinking have taken place. In this kind of pedagogic vision, it is presupposed that the role of the learner is not primarily to assimilate whatever one legal system presents. The constructivist approach suggests that the learner is more actively involved in a joint enterprise with the law teacher of constructing new legally relevant, and perhaps competing, meanings. Comparative law and/or foreign law and even approximate knowledge of different foreign approaches to similar types of questions may be regarded as a valuable tool for the construction of a primary pluralistic legal mind. ${ }^{5}$

\footnotetext{
${ }^{4}$ So, "a quickie version of international law" is simply not enough if we are to take transnational challenge seriously, as Anita Bernstein has pointed. See Bernstein, On Nourishing the Curriculum with a Transnational Law Lagniappe, 56 JoURNAL OF LEGAL EdUCATION 578, 593 (2006).

${ }^{5}$ If one has followed the intense debate within comparative law, one may raise one's eyebrows while reading expressions like "similar type of questions". Some might detect 'a functionalist bias' in this line of argumentation. For more details see, Jaakko Husa, Farewell to Functionalism or Methodological Tolerance?, 67 RABELS ZEITSCHRIFT FÜR AUSLÄNDISCHES UND INTERNATIONALES PRIVATRECHT, 419 (2003). Be that as it may, here the underlying idea is that law teaching and learning should be focused on something which is: "deeply rooted or profound...that which pervades all of" legal systems as H. Patrick Glenn puts it. See H. Patrick Glenn, Doing the Transsystemic: Legal Systems and Legal Traditions, 50 MCGILL LAW JoURNAL 863, 867 (2005).
} 


\section{B. Law Curriculum as a Hidden Epistemic Curriculum}

We may speak of a law curriculum in many senses. Obviously the most basic manner to conceive a law curriculum is to regard it as some kind of aggregate of courses given in a law faculty or law school. Accordingly, debate or discussion about a law curriculum tends to concern questions like: what courses should be included, how much material should include criminal law and how much should students study constitutional law or should the law curriculum be expanded also to cover other disciplines such as economics, political science, or sociology. Undoubtedly this is something that all academic law teachers are very much familiar with i.e. the constant battle between public law and private law or the eternal question of how much legal history and how much philosophy of law should necessarily be included. And, as we are well aware, comparativists have played their part in these debates. Such arch-type comparative lawyers as Konrad Zweigert and Hein Kötz have presented the standard comparative law argument by stressing the general importance of comparative law in all legal education: "Comparative law offers the law student a whole new dimension, from it he can learn to respect the special legal cultures of other peoples, he will understand his own law better...". ${ }^{6}$

Basically, comparative law adherents have said and are still saying that we should have more comparative law and foreign law included in national law curricula. As such, there is nothing wrong with this argument. The basic idea is to have deeper integration of comparative law into the teaching of national law. ${ }^{7}$ Certainly, these kinds of arguments and discussions are not irrelevant, however this kind of debate is not really what is sought after here. And, yet, what is claimed in this paper does not differ drastically from the old idea of comparativists that there should be more comparative and foreign law in law curricula. Nonetheless, the argument behind this outcome is constructed differently from the old ideas. More importantly, in some aspects the argument presented here is completely different from what has been said before about the role of comparative law in teaching. The key question here concerns law curricula and their clandestine dimension.

But what is there is in the law curriculum that does not meet the instant eye? During the 1960 s a concept of hidden curriculum was presented in the critical study of education. ${ }^{8}$ Without going into details of educational science one may generalise a great deal and claim that the most important single finding in the hidden curriculum debate was the fact that teaching and curriculum lost their innocence. In other words, it was brought into the

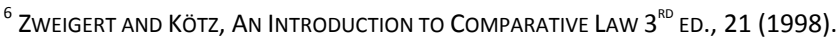

${ }^{7}$ Cf. Helmut Coing, European Common Law: Historical foundations, in NEW PERSPECTIVES FOR A COMmON LAW OF EUROPE 31-44 (Mauro Cappelletti ed., 1987) (national law's ideas presented against the common legal

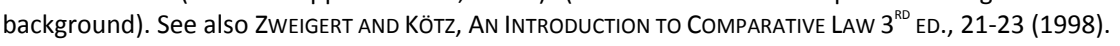

${ }^{8}$ See especially PHILIP JACKSON, LIFE IN THE CLASSROOMS (1968).
} 
open that while teachers teach and follow the official curriculum something else takes place i.e. it is not just offering knowledge and skills. There is also something else going on that does not meet the eye instantly. This something else is also very important in the teaching of law. The way studies are organised and the way different subject areas are positioned in the total-structure of a curriculum is a key factor in moulding the law student's way of thinking without thinking or questioning certain invisible theoretical commitments about law. Therefore, law curriculum is a sort of embodiment of how epistemic basic spheres like 'law', 'legal' or 'non-law' and 'non-legal', and 'valid law' and 'non-valid law' are understood. Doing so, law curriculum offers a representation of the inner order of the world of law. ${ }^{9}$ It makes one think like a lawyer, although, this outcome is not solely a learning product of official curriculum, but also a by-product of hidden epistemic curriculum (offering one-system-centred provincialism). In a similar vein, $H$. Patrick Glenn has rightly pointed out that:

"If law is no longer considered exclusively in terms of national sources, then it is the discipline of law in its entirety which must assume the cognitive burden of providing information on law beyond national borders." ${ }^{10}$

Law, from the point of view of world-of-law representation, is characteristically a national being and the boundaries of this "normal world of law" are that of the national legal system i.e. one system, the mother-system. Legal entities or dimensions like foreign, comparative or transnational entities come only as a form of supplement, which may enrich the nationally defined epistemology of law, but do not really challenge the national boundaries of "normal world of law". ${ }^{11}$ Implicit representation and verification of "normal world of law" is what is meant here by hidden epistemic curriculum: the picture that looks so ordinary that no professional lawyer in a country would question the basic parameters in it, even while many lawyers may have different ideas about the content of law itself. There may be more to it as Jan Smits' concept of "vicious circle" seems to suggest: in a nationally defined world a lawyer may end up being "better off simply studying national law". ${ }^{12}$ This is the outcome of thinking in which nationally applicable law is stressed heavily and in which foreign and comparative material, although interesting and even fascinating,

\footnotetext{
${ }^{9}$ In the sense of Heinrich Rickert (see HeINRICH RICKERT, THE LIMITS OF CONCEPT Formation In NATURAL SCIENCES (1986)), this representation is Darstellung, containing not only a form of conceptualisation (i.e. logical construct) but it also having a certain cognitive purpose.

${ }^{10}$ H. Patrick Glenn, Aims of Comparative Law, in Elgar Encyclopaedia of Comparative Law 57, 59 (Jan Smits ed., 2006).

${ }^{11}$ International law (both public and private) is left out here on purpose. This is done because public and private international law is actually based on certain commitments that in many senses embrace the idea of sovereign state and its law; the international aspect is subjugated to this primary national/state law dimension. In accord, transnational legal questions do not concern only international lawyers (see supra note 1, 748).

12 Jan Smits, The Making of European Private LaW, 55 (2002).
} 
does not appear legally relevant. From the point of view of legal education, the epistemic outcome may be described by the words of W.J. Kamba: "One is inclined to think that the solutions of one's own legal order are the only possible ones". ${ }^{13}$ So, it is not claimed that one necessarily prefers one's own law knowingly, but that one is in an epistemic sense inclined to do that. As such, this is certainly not anything new for traditional comparative law where it has always been understood that the law that is taught, "fixes the minds of those who administer the respective legal systems" ${ }^{14}$

\section{Legal Weltanschauung}

Globalisation and the expansion of transnational law changes law in the sense of rules, principles, institutions and procedures. But to truly deal with this change something more than knowing the new body of law is needed. In a similar vein, it has been recently noted that we need not only globalisation of law or legal science but rather "a globalisation of the mind". ${ }^{15}$ To globalise the mind has necessarily also to do with the epistemic legal curriculum.

What is sought after is to claim that when one follows a curriculum it is not only important what is in the curriculum but also what places different subject areas are to be found, and in what order they are presented to law students. For instance, if comparative law or foreign law comes only at the very late stages of studying, it also reflects an implicit idea concerning the "right place" of these subject areas in the world of law; they come only after the 'normal stuff' and represent something that is 'extra'. The theoretical character of comparative law teaching tends to fortify this impression of 'extra'. This is a kind of legal Weltanschauung or world-view-of-law that contains the epistemologically defined manners, which a professional law person uses when he or she is trying to perceive the world of law. ${ }^{16}$ In this sense law may be conceived as a form of discourse because there is no direct cognitive access to legal reality. ${ }^{17}$ The world of law cannot be touched or seen and yet no jurist would deny that in some miraculous way it simply exists. But, how does comparative and foreign law fit in?

\footnotetext{
${ }^{13}$ W.J. Kamba, Comparative Law: A Theoretical Framework, 23 INTERNATIONAL AND COMPARATIVE LAW QUARTERLY 485, 491 (1974).

${ }^{14}$ Hessel E. Yntema, Comparative Law and Humanism, 6 American Journal of Comparative LaW 493, 499 (1958).

${ }^{15}$ Xavier Blanc-Jouvan (partly quoting Harry Arthur), Book Review: The Oxford Handbook of Comparative Law (Mathias Reimann and Reinhard Zimmerman eds.), 56 American Journal of Comparative LaW No. 4, 1076, 1084 (2008).

${ }^{16}$ About the concept of Weltanschauung, see e.g. HANS-GeORg GAdAMER, TRUTH AND METHOD 98-99 (1994). Here this philosophical concept refers to a shared comprehensive mental image of world of law in general.

${ }^{17}$ See also Gunther Teubner, How the Law Thinks: Toward a Constructivist Epistemology of Law, 23 LAW \& SOCIETY REVIEW, 727, 743 (1989).
} 
Comparative law or the study of foreign law may be regarded as a form of competing discourse as it could offer a different way for organising the world of law and different ways of how to seek answers to social problems that are regarded as having something to do with legal order. The problem is, however, that comparative law and foreign legal material have a very small role in law curricula around the globe; this is true regarding the amounts as well as the positioning of comparative and foreign law material in curricula. In the circles of comparative law, the criticism of law curricula being too provincial or parochial are, of course, well known and widely spread. And yet, it is very much the standard manner to have little if any comparative and foreign law material in a curriculum. In most typical cases comparative and foreign law may be chosen freely as supplementary studies at the very late stages of studying. ${ }^{18}$ Paradoxically, this does not differ drastically from what many classical comparativists have said about the educational role of comparative study of foreign law: that it is an auxiliary educational tool having a role in lawyer education. ${ }^{19}$ The crucial pedagogical question is, however: is this auxiliary or complementary role enough for contemporary purposes?

Some things appear to be quite clear. Without a shadow of a doubt, little comparative and foreign law is better than none, but from a pedagogical point of view this is way too little in order to help constructing genuinely competing legal discourses alongside one's own national law. ${ }^{20}$ This is simply because the hidden epistemic curriculum has already been implicitly constructed in a much earlier phase. To put it concisely: too little and too late. Accordingly, even though a student may learn some details or technicalities of foreign law she or he does not really receive alternative ways to think 'legally right'. Grand theories of comparative legal science or comparative legal studies do not change the prior epistemic embedding that has already taken place. Moreover, this also means that the challenge to teach lawyers to think like global lawyers is generally not met. ${ }^{21}$ So, the question boils down to this: where else should comparative/foreign law be placed then? it is common wisdom that one must first know one's own law and only after having gained this

\footnotetext{
${ }^{18}$ It is not necessary to go into the details of thousands of law curricula here. However, based on my own experiences and quite extensive internet searches, the state of affairs, which is referred to above in the text, appears to be the most common. Also inquiries from colleagues have produced largely the same result. In this context I thank specifically Professors Michael Bogdan, H. Patrick Glenn, and Mathias Siems for providing their own personal findings concerning the use and role of comparative law in countries that they are familiar with. For a larger European picture see also Juristenausbildung in der Europäischen Union (http://www.europaeischejuristenausbildung.de), last accessed 17 June 2009.

${ }^{19}$ See, e.g., Ernst Rabel, Aufgabe und Notwendigkeit der Rechtsvergleichung, in GESAMMELTE AUfSÄTZE BAND III, 1921 (1967, originally published in 1924) on "Bildungselement", and PIERRE ARMINJON, Boris Nolde, MARTIN WolfF, TRAITÉ DE DROIT COMPARÉ TOME I 14-18 (1950) on "rôle educatif".

${ }^{20}$ Even in the best, most well intentioned attempts aim to integrate a supplementary "component in the national legal education" (supra, note 12, 56).

${ }^{21}$ Here the text is in debt to Catherine Valcke who has offered an inspiring argument to this discussion in her seminal article Catherine Valcke, Global Law Teaching, 54 Journal of LEGAL EduCATION 160 (2004).
} 
epistemic basic embedding may one safely enter into such perilous areas as comparative and foreign law. Furthermore, of course one needs to know about theories and methodologies of the comparative study of law before anything can be done properly. Are these ideas not part of the healthy common comparative law wisdom that should be respected and followed? Perhaps this is not the case. Now, what is argued in the following is completely opposite to most traditional wisdom concerning legal education and learning. 22

\section{Clearer Distinction between Research and Tool for Education}

In the above it has been claimed that national law in the epistemic sense dominates national law curricula: it has an important position in constructing the invisible and implicit legal Anschauung, or immediate intuition, of a legal mind. If this is so, then we might regard national law as a kind of epistemic community. In this community, legal professionals from a variety of fields of law and professional backgrounds have a shared set of normative and principled beliefs, which provide rationale for the action of community members in their capacity as legal professionals. This legal epistemic community has also shared causal beliefs concerning possible legal solutions and their desired social outcomes: what rule should be applied and what rule should not be applied, how and where to find these rules etc. Also shared notions of validity are part of this community i.e. there are internally defined criteria for weighing and validating knowledge in the domain of their legal expertise (to answer what is valid law and what is not). And finally, this epistemic community also has a set of common professional practices associated with a set of legal problems to which their professional competence is directed. These common professional practices are based on implicit conviction of "right" legal solutions or "proper" way to look and assess legal dimensions in social problems (i.e. members of the community think like lawyers). In a word, this epistemic community has a shared legal-world-view, which is not openly displayed, and yet it exists. ${ }^{23}$ The law curriculum is a part of this epistemic community and they cognitively initiate students to this community.

Now, legal education is not itself the same as this epistemic community, but what education does is take part in constructing this epistemic community (or to be precise builds some of its basic ontological and epistemological commitments about law) by providing a world-view-of-law, which is based on one national system i.e. monounderstanding. What follows, is a certain way to conceive one's own law as being 'natural'

\footnotetext{
${ }^{22}$ Education refers in this text to the process of acquiring legal knowledge or skills. Learning, on the other hand, refers to those skills and knowledge which are acquired by systemic study of law (i.e. following the curriculum).

23 These ideas (or rather applications of certain ideas) originate from PETER M. HAAS (ED.) INTERNATIONAL ORGANISATION, 46 (1992).
} 
and other laws as 'not-natural'. ${ }^{24}$ The learning outcome, provided by the hidden epistemic curriculum, is a kind of a mono-system-thinking, which has proved to be a problem for today's and tomorrow's legal education, because legal education should be able to answer the call of the wild i.e. face the promises and perils of transnational legal education. ${ }^{25}$ Here it is suggested that comparative/foreign law might have an important role in this, but there are some problems with this. If one reads comparative law literature at all, one cannot avoid the fatherly atmosphere in which older and more seasoned comparativists are constantly reminding their younger colleagues about studying foreign law carefully and not making any such foolish assumptions that originate from their own legal cultural background. ${ }^{26}$ In fact, much of the comparative law literature genre consists of warnings stressing the perils and difficulties lurking behind every corner. It is all so a very serious business, which, accordingly, starts to look very much as something for only those truly initiated. $^{27}$ Surely, this risky field of ambitious legal science cannot form the base of law teaching even in the transnational world? Or could it?

hese warnings make perfect sense if we are dealing with the comparative research of law i.e. comparative law or comparative legal studies as a separate academic field of legal science. $^{28}$ However, it may be useful to separate the teaching of law (especially at undergraduate level) and the research of law when we are dealing with comparative law. From the perspective of teaching, comparative law should not be understood exclusively as a field of legal science but rather as a pedagogical instrument. ${ }^{29}$ Now, if comparative/foreign law's full pedagogical potential is going to be used we cannot simply start from similar ideas about the required skills: first year students and professors at the age of sixty do not have similar skills. Accordingly, if comparative law material is going to be situated in the curriculum in a very early phase (first year or second year) it is practically

\footnotetext{
${ }^{24}$ This is very close to Valcke's (supra, note 21,177 ) idea according to which this kind of globally oriented law teaching offers a possibility to: "penetrate another system, to decipher the 'law in minds'...to get acquainted with a new way of thinking".

${ }^{25}$ See Second Call for Contributions to contribute to a Symposium Issue of the German Law Journal: "Following the Call of the Wild: The Promises and Perils of Transnationalizing Legal Education". Online at: http://www.germanlawjournal.com/article.php?id=1010. Last accessed, 17 June 2009.

${ }^{26}$ See Michael Bogdan, Comparative LaW, 48-50 (1994).

${ }^{27}$ Much of Pierre Legrand's work seems to say that comparative law/legal studies are not for everyone. See, e.g., Pierre Legrand, How to Compare Now? 16 Legal Studies 232, 239 (1996).

${ }^{28}$ Of the high scholarly ambit in the field see, e.g., Nicholas HD Foster, The Journal of Comparative Law: A New Scholarly Resource, 1 JOURNAL OF COMPARATIVE LAW 1 (2006) for comparative law or rather comparative legal studies being a necessary science of tomorrow.

29 Traditionally comparative law has been deemed to have many purposes of which one has always been education. See, e.g., Otto Kahn-Freund, On Uses and Misuses of Comparative Law, 37 MODERN LAW REVIEW 1 (1974) for comparative law seen as a tool of research, tool of education, and tool of law reform.
} 
impossible for any of the students to have the required skills. So, comparative/foreign law as a teaching-tool must be separated from comparative law scholarship. And, the requirements concerning these two must also be different. ${ }^{30}$ This is not as easy to conceive of as it may appear, $m$ because it would require turning upside down some of the most persistent paradigmatic wisdoms in comparative law. Namely, what is required is to abandon, in the teaching-context, the famous idea of Paul Koschacker according to which: "Schlechte Rechtsvergleichung ist schlimmer als keine." (Bad comparative law is worse than none.) $)^{31}$

But, if we are to use comparative law as a fully-flexed educational tool it might, instead, make perfect sense to have a 'bad comparison' provided that 'bad comparison' may produce a better epistemic embedding for law studentss legal minds i.e. better learning results in the long run. The core pedagogical point here is straightforward: to try to make students to actually attempt to use the laws of systems that differ from their own. In order to make this idea clearer we should look into different theories about education and learning. In this respect, the constructivist ideas look especially promising.

\section{Constructivist Law Curriculum?}

Constructivism in education or in educational psychology may be regarded as a certain kind of loose theoretical approach to teaching and learning. Its core idea is to regard each individual learner as an active person who is actively building or constructing knowledge and skills. ${ }^{32}$ In previous theories about learning, the information was provided by the teacher and the role of learners was passive in their relation to the teacher who was providing the knowledge and skills that were needed to be learnt. Rather, in constructivism it is thought that information exists within the constructs made by learners themselves as opposed to in any external environment provided by the teacher. The material provided by the teacher is regarded as a kind of stimulus that sets the learner's learning process into motion i.e. the stimulus (what is taught) is not as important as the cognitive process that stimulus is producing in active learners. So, learning is regarded as an active process in which learners construct new ideas or concepts based upon their current or past knowledge.

\footnotetext{
${ }^{30}$ In a similar vein it has already been suggested that as a subject comparative law should be integrated into other law courses. See, e.g., Mathias Reimann, The End of Comparative Law as an Autonomous Subject, 11 TULANE EUROPEAN AND CIVIL LAW FORUM 49 (1996).

${ }^{31}$ Quote taken from LÉONTIN-JeAn CONSTANTINESCO, TRAITÉ DE DROIT COMPARÉ TOME II, 15 (1974).

${ }^{32}$ This is very much what Kamba (supra, note 13, 492-493) has said about comparative law's role in legal education: "The student is compelled to question the soundness of the solutions, norms and many other aspects of his own law...prompted to investigate the inarticulate assumptions on which the institutions of his own law rest".
} 
What the learner actually does is select and transform information, construct hypotheses, and make decisions, relying on a cognitive structure to do so. In this kind of process it is the cognitive structure (e.g. schema or a mental model) that provides meaning and organisation to experiences and allows the learner to go actually beyond the information given. In this kind of process the teacher or rather the instructor tries to get students to discover 'legal things' by themselves. Further, the teacher and the learner should engage in an active dialog, which facilitates the process of learning. ${ }^{33}$

The idea is not to forget to teach skills but to change the manner in which the required skills are taught; skills are taught and learned discretely. In this kind of constructivist theory of learning there are some basic principles that should be followed. We may mention two of those principles here. An important principle is to structure the teaching so that it may be easily understood by the student. In other words, students should have an active role in law learning. The second important principle is to design the teaching so that it would help students learn to fill the gaps. This is precisely what is meant by, "going beyond the information given". What is hoped for in this kind of teaching is to help students to expand and further develop their knowledge by enhancing their willingness to go further toward new learning. Or as the participants in NACLE transnational family law experiment formulate it, though without referring to constructivist learning theories: "Students would therefore be called upon to research....". ${ }^{34}$

Of course, all this may sound nice and all, but we may wonder how this works in practice. ${ }^{35}$ It is not the task of this paper to delve deep into the practical issues, yet something seems to be very clear. ${ }^{36}$ There are at least two points which are important to take into account. The first one deals with the nature of questions that can be used in the early-phase of comparative/foreign law teaching. To begin with, we should not start from classical

\footnotetext{
${ }^{33}$ These ideas here are all based on the groundbreaking work of Jerome Bruner. For a larger picture of his work see, Jerome Bruner, Toward a TheOry of InStruction (1966), GoIng Beyond the Information Given (1973), Actual MINDS, POSSIBLE WORLDS (1986), and ACTS OF MEANING (1990). Obviously, constructivism is a large framework in philosophy and science and the ideas of Bruner represent only one stream, even though from the point of view of education Bruner's ideas are most likely best known.

${ }^{34}$ Supra note 2, 544. This would be needed in order "to encourage...to research and analyze the legal questions on its own, much as students will have to do after graduation" (id. 550).

${ }^{35}$ In practice, it may be a true challenge, see Atwood, supra, note 2, 552-557.

${ }^{36}$ In practice, such attempts as the NACLE Cross-Border Family Law Module is one possible practical example of how to involve the deep and practical comparative/foreign law dimension into the law courses in three different jurisdictions and three different legal languages, see Atwood, supra note 2. Also the transsystemic or bijural teaching (at undergraduate level) at McGill University in Canada offers another type of practical example. See for more detailed discussion Yves-Marie Morissette, McGill's Integrated Civil and Common Law Program, 52 JouRnaL of Legal Education 12 (2002). See also H. Patrick Glenn, Doing the Transsystemic: Legal Systems and Legal Traditions, 50 MCGILL LAW JOURNAL 863, 865-866 (2005) on explaining the theoretical background of studying simultaneously, in the same classroom, civil law and common law.
} 
comparative law questions like: "What is comparative law? What are its purposes? What are the subject's particular aims, approaches, methods, and how is it used?" ${ }^{\prime 37}$ These do not enhance the readiness of students to be willing and able to learn, but rather, they may even block the growth of interest and direct the focus to points that are overtly theoretical and do not seem fascinating to an average law student. Rather, we should start from questions (i.e. stimuli) that are as to their nature something like: "Is the administration liable on the same basis as a private individual? How far is compensation sought through the courts and how far are there special compensation schemes for particular kinds of injury or activity?" ${ }^{38}$ These are the kind of questions that do not require students to know about foreign law extensively or their own law for that matter. In other words, questions like these practical ones can be answered roughly with the help of some valid basic legal literature of a country. Further, these kinds of practical questions (being "answered" in simulation-type exercises) also teach the student implicitly that there are different approaches to the same type of questions. ${ }^{39}$ All this would probably help to build the epistemology of law that resides on multiplicity rather than mono-systemic legal thinking.

This, nevertheless, is in direct opposition to the classical paradigm concerning using comparative law as a tool in teaching. Namely, it has been suggested by Kamba that it is of importance first to know about the theories of comparative law and things like methodology, classification and general features of legal systems. ${ }^{40}$ Now, if one seeks accurate knowledge about foreign law Kamba's idea is certainly plausible. However, if one uses comparative/foreign law material as a constructivist tool in primary legal learning while building the legal epistemology of a learner (undergraduate), then, the situation may be completely different. Instead of accurate and rigorously gained knowledge, comparative/foreign material would be used to build a legal mind that starts from many possible solutions, instead of one legal base, with the additives of "something extra", something "not normal".

The other important question has to do with the role of the law teacher. ${ }^{41}$ It seems clear that law teachers should pose rather general legal questions and then require the students to find out themselves. Obviously, the material used may be defined in the curriculum and

\footnotetext{
${ }^{37}$ Esin Örücü, Developing Comparative Law, in COMPARATIVE LAW: A HANDBOOK, 42, 63 (Esin Örücü and David Nelken eds., 2007).

${ }^{38}$ John Bell, Administrative Law in a Comparative Perspective, in Comparative LAW: A HANDBook, 287, 310 (Esin Örücü and David Nelken eds., 2007).

${ }^{39}$ Theoretically this seems to require accepting some kind of universalism or generalist assumption according to which there, indeed, are common legal questions in different legal systems.

${ }^{40}$ See supra note $13,518-519$.

${ }^{41}$ This concerns multiple aspects: description of given assignment, discerning and building a meaningful learning objective, gathering suitable readings for the assignment etc.
} 
the teacher is there to provide help as to how to use this material, and how to read textbooks about foreign law while trying to find out about different approaches. ${ }^{42}$ The teacher has great significance in this kind of teaching because there is always a risk that those students who have poorer skills do not simply make any true progress in their learning. So, it is highly relevant for the teacher to keep those students without adequate basic-abilities up to speed with the learning process. This is simply because there is an inevitable risk that some of the students may adequately develop their skills, but may still have gaps in their legal knowledge and skills that are based on that knowledge. Also there is a further risk that the teacher must try to avoid: students may develop knowledge and skills in legal thinking and making legal questions and finding different answers to those questions, but all this may possibly have no meaning to the learner who may end up stressing the importance of national law. And, there is always a risk that the comparative/foreign law knowledge and skills may be forgotten.

In more practical terms, if comparative law and foreign law would be taught in the way that has been proposed here, we may assume that the second and third year of law school would be possible places to include it in the law curriculum. ${ }^{43}$ Also, it is not difficult to grasp that these sorts of courses should not involve classical lecturing but rather lengthy seminars requiring those taking part to concentrate fully on the learning process. The first year of the studies should be reserved for such basic skills as languages, computer skills and general legal studies and/or legal theory. In any case, these sorts of comparative/foreign law courses or rather large study-modules should have much larger roles in the curriculum than is the situation today. This is, of course, only if we want to take seriously the transnational challenge to legal education. To be sure, what is not meant here is "modest, supporting role in introductory courses" as has been suggested by one American professor. ${ }^{44}$ Accordingly, the task suggested here may be just too huge to be realistic: national traditions are very influential in shaping thinking about education and university reform. ${ }^{45}$ Without a shadow of a doubt, turning the law curriculum upside down might be regarded by most law professors as sacrilege.

\footnotetext{
${ }^{42}$ Of course the number of comprehensible legal languages and availability of relevant materials pose certain restrictions, although Internet has to an extent diminished some of the difficulties. For a more detailed discussion on the significance of linguistic skills see HeIKKI MATTILA, CoMPARATIVE LEGAL LINGUISTICS 19-21, 33-39 (2006).

${ }^{43}$ This refers to the undergraduate type of law program. If a law programme is a graduate programme, then this does not fully fit. However, this paper keeps in mind especially European law programmes of which most are fiveyear programmes consisting of both undergraduate and graduate level law study. In the American scene, however, things are somewhat different.

${ }^{44}$ Neil S. Siegel, Some Modest Uses of Transnational Legal Perspective in First-Year Constitutional Law, 56 JouRnAL of Legal Education 201, 215 (2006). See also M.C. Mirow, Globalizing Property: Incorporating Comparative and International Law into First Year Property Class, 54 JouRnal of LEGAL EdUCATION 183 (2004).

${ }^{45}$ See supra note 1,749 . It seems that he certainly has a point when stating that: "While this insight is beginning to take hold in curriculum reform committees everywhere, there is still a long way to go to bridge the gap
} 


\section{E. Conclusion - Toward Multijuralism?}

The preliminary discussion above suggests that comparative/foreign law might gain a novel function in a (hidden epistemic) law curriculum designed to better serve the construction of the pluralistic legal mind for the transnational legal world. At the beginning of this paper it was argued that the problem with the traditional law-teaching approach is that it constructs a primary epistemic foundation for the legal understanding, which is based on one mother-system. What is suggested above, is the promotion of a change in the manner of how legal curriculum is constructed and especially how comparative/foreign material is taken in and how it is taught. The crucial dimension in this cursory argument is the clear separation of comparative law as an educational tool from the comparative research of foreign law; what works in education might not fit at all in serious comparative research and vice versa. When stressing the importance of law curriculum as a builder of the legal epistemology of a learner and when relying on constructivist learning theory, the accurateness of comparative/foreign material is not the primary concern; rather what is crucial is the primary experience of world-view-of-law in which there are several possibilities and one's own national law is seen - from the very beginning - as only one possible path to (legally) arrive at a solution.

The proposed change contains both qualitative and quantitative elements. When it comes to quality the idea is to build the legal learning so that law students start from questions rather than answers provided by one national system. This would probably make it easier for future lawyers to adapt to different legal cultures and different non-national bodies of law, which overlap with the national law. Simply, the first question might be, 'from what legal materials, stemming from various sources, can we find those solutions that might lead us to solve the present legal problem' instead of 'in my legal system?...'. Quantitatively speaking, obviously the amount of comparative and foreign law material should be larger than what it normally tends to be. Importantly, this does not only concern the teaching of transnational law as such, but perhaps even more importantly it would facilitate law students' possibilities to actively construct a plural epistemology of law; law learners would become "more aware of the range of possible legal responses to common...disputes" ${ }^{46}$ In practice, this would require taking a step further from McGill's famous transsystemic/bijural thinking toward transsystemic/multijural type of thinking. In short, this would mean simultaneously studying in the same classroom fully transsystemically i.e. mixing civil law, common law, chtonic law, Nordic law etc. So, instead

between the mostly traditional canon of First Year courses and the crème de la crème curriculum specializations that are usually restricted to Upper Year programmes" (id).

${ }^{46}$ Supra, note 2, 549. 
of two kinds of solutions (common law or civil law) we might have more solutions when the jurist goes beyond the legal information given by any one system. ${ }^{47}$

All this, of course, requires not only injecting more comparative/foreign material into law curricula, it requires some kind of pedagogic vision. Catherine Valcke has rightly pointed out that too little attention has been paid to the question concerning the overall pedagogic design of injecting transnational/global material into the law curricula. She has criticised the fact that "coherent pedagogical vision" is lacking. ${ }^{48}$ Now, it is not possible to boldly claim that constructivist learning theory would solve this problem effortlessly; however, it does seem like a fare possibility if we are trying to find ideas of how to build the lacking coherent pedagogical vision. And, if we are not able to step into a world in which law curricula might follow these ideas presented here, we may at least hope that the growth in number of study-modules that embrace such a hidden epistemic curriculum would more and more enable the cultivation of a kind of legal Anschauung that would make it cognitively easier for future lawyers to adapt in pluralistic global and transnational law. As pointed out already fifty years ago by Hessel E. Yntema, the main goal for comparative legal instruction is to provide jurists of the future adequate general preparation for facing new problems of a changing world. ${ }^{49}$

An effective law curriculum of today is that which can stimulate students to learn legal thinking without being hopelessly stuck in an epistemic sense with one's own legal system. But to acquire this, something more than a few more piecemeal courses in traditional international law and theoretical comparative law are required: most crucially students should be made able to construct their own legal understanding from various competing and overlapping sources. Finally, this would mean that the law teacher would be more of a law instructor or a legal education coach structuring the student's learning of law as a joint enterprise with the law student. To say the least, this would offer something else than simply giving lengthy and tedious reprimands to an audience of law students who can barely stay awake.

\footnotetext{
${ }^{47}$ When stepping out from the bijural thinking, one might really approach near to the kind o outcome described by H. Patrick Glenn. See H. Patrick Glenn, Doing the Transsystemic: Legal Systems and Legal Traditions, 50 McGILL LAW JOURNAL 863, 866, following: "Legal education would necessarily have to track, and even foreshadow," various non-positivist developments within legal theory/philosophy.

${ }^{48}$ Supra, note $21,160$.

${ }^{49}$ See supra, note $14,499$.
} 